\title{
System Evaluation and
} Life-Cycle Cost Analysis of a Commercial-Scale High-Temperature Electrolysis Hydrogen Production Plant

\section{IMECE2012}

The INL is a

U.S. Department of Energy

National Laboratory

operated by

Battelle Energy Alliance

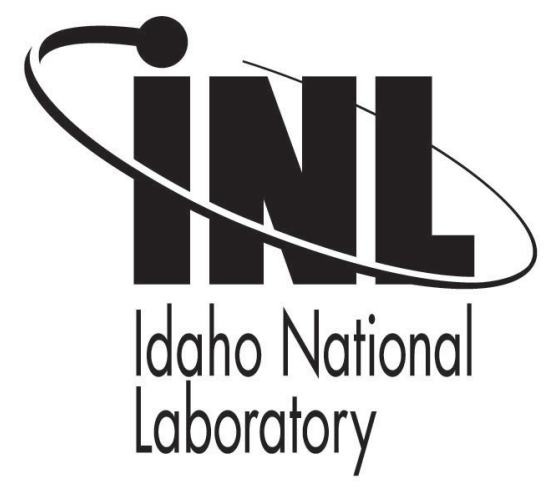

\section{Edwin A. Harvego \\ James E. O'Brien \\ Michael G. McKellar}

November 2012

This is a preprint of a paper intended for publication in a journal or proceedings. Since changes may be made before publication, this preprint should not be cited or reproduced without permission of the author. This document was prepared as an account of work sponsored by an agency of the United States Government. Neither the United States Government nor any agency thereof, or any of their employees, makes any warranty, expressed or implied, or assumes any legal liability or responsibility for any third party's use, or the results of such use, of any information, apparatus, product or process disclosed in this report, or represents that its use by such third party would not infringe privately owned rights. The views expressed in this paper are not necessarily those of the United States Government or the sponsoring agency. 


\title{
SYSTEM EVALUATION AND LIFE-CYCLE COST ANALYSIS OF A COMMERCIAL- SCALE HIGH-TEMPERATURE ELECTROLYSIS HYDROGEN PRODUCTION PLANT
}

\author{
Edwin A. Harvego, James E. O'Brien and Michael G. McKellar \\ Idaho National Laboratory \\ Idaho Falls, ID 83415, USA
}

\begin{abstract}
Results of a system evaluation and lifecycle cost analysis are presented for a commercial-scale high-temperature electrolysis (HTE) central hydrogen production plant. The plant design relies on grid electricity to power the electrolysis process and system components, and industrial natural gas to provide process heat. The HYSYS process analysis software was used to evaluate the reference central plant design capable of producing $50,000 \mathrm{~kg} /$ day of hydrogen. The HYSYS software performs mass and energy balances across all components to allow optimized of the design using a detailed process flow sheet and realistic operating conditions specified the analyst. The lifecycle cost analysis was performed using the H2A analysis methodology developed by the Department of Energy (DOE) Hydrogen Program. This methodology utilizes Microsoft Excel spreadsheet analysis tools that require detailed plant performance information (obtained from HYSYS), along with financial and cost information to calculate lifecycle costs. The results of the lifecycle analyses indicate that for a $10 \%$ internal rate of return, a large central commercial-scale hydrogen production plant can produce $50,000 \mathrm{~kg} / \mathrm{day}$ of hydrogen at an average cost of $\$ 2.68 / \mathrm{kg}$. When the cost of carbon sequestration is taken into account, the average cost of hydrogen production increases by $\$ 0.40 / \mathrm{kg}$ to $\$ 3.08 / \mathrm{kg}$.
\end{abstract}

\section{NOMINCLATURE}

$\begin{array}{ll}\text { CO } & \text { Carbon Monoxide } \\ \text { CO2 } & \text { Carbon Dioxide } \\ \text { DCF } & \text { Discounted Cash Flow } \\ \text { DOE } & \text { Department of Energy } \\ \text { HTE } & \text { High-Temperature Electrolysis } \\ \text { HYSYS } & \begin{array}{l}\text { Process analysis software developed by } \\ \text { Aspen Tech }\end{array} \\ \text { H2 } & \text { Hydrogen } \\ \text { H2A } & \text { Hydrogen Analysis } \\ \text { HX } & \text { Heat Exchanger } \\ \text { INL } & \text { Idaho National Laboratory } \\ \text { IRR } & \text { Internal Rate of Return }\end{array}$

\author{
MACRS Modified Accelerated Cost Recovery System \\ O\&M Operation and maintenance \\ O2 Oxygen \\ SOE Solid Oxide Electrolyzer
}

\section{INTRODUCTION}

This paper presents results of a system evaluation and lifecycle cost analysis performed for a commercial-scale hightemperature electrolysis (HTE) hydrogen production facility. The primary advantage of high-temperature electrolysis over conventional electrolysis, which is a well established technology, is that considerably higher overall efficiencies can be achieved. The improved performance of HTE compared with conventional low-temperature (alkaline or PEM) electrolysis is directly related to the high temperature operation, which influences both the thermodynamics and electrochemical kinetics of the process. From thermodynamics, the electrical energy required for water or steam electrolysis decreases with increasing temperature, while the thermal energy requirement increases. Consequently, at higher temperatures, a larger fraction of the total electrolysis energy input can be supplied in the form of heat, increasing the overall process efficiency. In terms of electrochemical kinetics, activation and ohmic overpotentials also decrease dramatically with temperature [1]. The resulting improved performance of HTE compared to conventional low-temperature water electrolysis is discussed in Reference 2 for large-scale hydrogen production using nuclear energy. The reduced electrical demand for the HTE process ( $\sim 32 \mathrm{~kW}-\mathrm{hr} / \mathrm{kg}$ of $\mathrm{H} 2$ produced) compared to conventional water electrolysis ( $48 \mathrm{~kW}-\mathrm{hr} / \mathrm{kg} \quad \mathrm{H} 2$ produced) is also discussed in Reference 3.

For this study, the HYSYS process analysis software was used in the detailed analysis of a HTE central plant design with a capacity of $50,000 \mathrm{~kg} /$ day. The HYSYS process analysis software inherently ensures mass and energy balances across all components and it includes thermodynamic data for all chemical species. The optimized design described in this paper is based on analysis of the HYSYS process flow diagram that 
included realistic representation of fluid conditions, and component efficiencies and operating parameters throughout the system. As with previous HTE system analyses performed at the INL, a custom electrolyzer model was incorporated into the overall process flow sheet. This electrolyzer model allows for the determination of the average Nernst potential, cell operating voltage, gas outlet temperatures, and electrolyzer efficiency for any specified inlet steam, hydrogen, and sweepgas flow rates, current density, cell active area, and external heat loss or gain.

The lifecycle cost analysis was performed using the H2A analysis methodology developed by the Department of Energy (DOE) Hydrogen Program. This methodology utilizes Microsoft Excel spreadsheet analysis tools that requires detailed plant performance information (obtained from HYSYS), along with financial and cost information to calculate lifecycle costs. There are standard default sets of assumptions (discussed later) that the methodology uses to ensure consistency when comparing the cost of different production or plant design options. However, these assumptions may also be varied within the spreadsheet when better information is available or to allow the performance of sensitivity studies. In addition to calculating the base cost of hydrogen production, the H2A central plant analysis spreadsheet used in this analysis also calculates the cost of carbon sequestration.

The following sections begin with a description of the HTE design concept for a $50,000 \mathrm{~kg} /$ day reference central hydrogen production plant design along with operating conditions and performance parameters used to develop the lifecycle cost estimate. The reference plant design utilized industrial natural gas-fired heaters to provide process heat, and grid-supplied electricity to provide power to the electrolyzer modules and system components. Required inputs for the lifecycle cost estimate are then presented, along with the results of the estimated hydrogen production cost ( $\$ / \mathrm{kg}$ of hydrogen). Subsequent sections then describe sensitivity studies performed for the reference plant design and present conclusions of this study.

\section{REFERENCE CENTRAL HYDROGEN PRODUCTION PLANT DESIGN}

As indicated above, the INL selected reference design for this study is a commercial-scale $50,000 \mathrm{~kg} /$ day central HTE hydrogen production plant that uses natural gas-fired heaters to supply process heat and grid electricity to power the electrolysis process and system components. In this HTE process, high-temperature steam at $800^{\circ} \mathrm{C}$ and $5 \mathrm{MPa}$ is delivered to the cathode side of the electrolyzer where it is electrolytically reduced, producing hydrogen as a primary product and oxygen as a byproduct. The oxygen that is evolved on the anode side of the electrolyzer is removed using a steam sweep system. Residual steam is removed from both the hydrogen and oxygen streams exiting the electrolyzer by condensation to yield the dry hydrogen product and oxygen byproduct gases. For the reference design, the electrolyzer was operated in the thermal-neutral mode where the ohmic heating associated with the various stack resistance mechanisms equaled the endothermic cooling of the steam reduction process. This operating point results in a constant temperature adiabatic process that eliminates the need for heating or cooling of the electrolyzer. In addition, as described below, the reference design utilized recuperative heat exchangers to minimize the required net high temperature process heat requirement, and to maximize overall hydrogen production efficiency.

The HYSYS-generated process flow diagram for the reference HTE hydrogen production plant capable of producing approximately $50,000 \mathrm{~kg} /$ day $(2095 \mathrm{~kg} / \mathrm{hr})$ of hydrogen is shown in Figure 1. The process flow model was developed to include all the major components that would be present in the actual plant, including pumps, compressors, heat exchangers, and heaters. With realistic system boundary conditions and component efficiencies and operating parameters input to the process, HYSYS performed energy and mass balances to predict fluid conditions around the system, and resulting hydrogen and oxygen production rates.

In the process flow diagram shown in Figure 1, the processed water feedstock enters at the left in the diagram. The water is then raised to the HTE process pressure of 5.0 MPa in the liquid phase using a pump (Make-up Water Pump). Downstream of the pump, condensate from the water knockout tank is recycled back into the inlet stream at MIX-102. The inlet water stream is then heated in Regenerator 1, which recovers heat from the post-electrolyzer hydrogen/steam outlet stream. Downstream of the regenerator, at the $\mathrm{H} 2 / \mathrm{H} 2 \mathrm{O}$ Mixer, the steam is mixed with recycled hydrogen product gas. A fraction of this product gas is recycled in this way in order to assure that reducing conditions are maintained on the steam/hydrogen electrodes in the HTE stacks. Downstream of the mixer, the inlet process steam/gas mixture enters Regenerator 2, where additional heat is recovered from the post-electrolyzer hydrogen/steam outlet stream. The inlet process stream then enters the natural gas-fired heater (Process HX 1) where final heating to the electrolysis operating temperature of $800^{\circ} \mathrm{C}$ occurs. The inlet process stream then enters the electrolyzer, where oxygen is electrolytically removed from the steam, producing hydrogen and oxygen.

Downstream of the electrolyzer, the hydrogen - rich product stream flows back through the two regenerators described earlier where the product stream is cooled and the inlet process stream is preheated. The product stream is cooled further at the H2/Water Knockout Tank, where the majority of any residual steam is condensed and separated; yielding dry hydrogen product. The cooled product stream is split at TEE101 and a fraction of the product gas is recycled into the inlet process stream, as discussed previously. A recirculating blower (H2 Recirc) is required to repressurize the recycled hydrogen stream to the upstream pressure at the $\mathrm{H} 2 / \mathrm{H} 2 \mathrm{O}$ Mixer. 


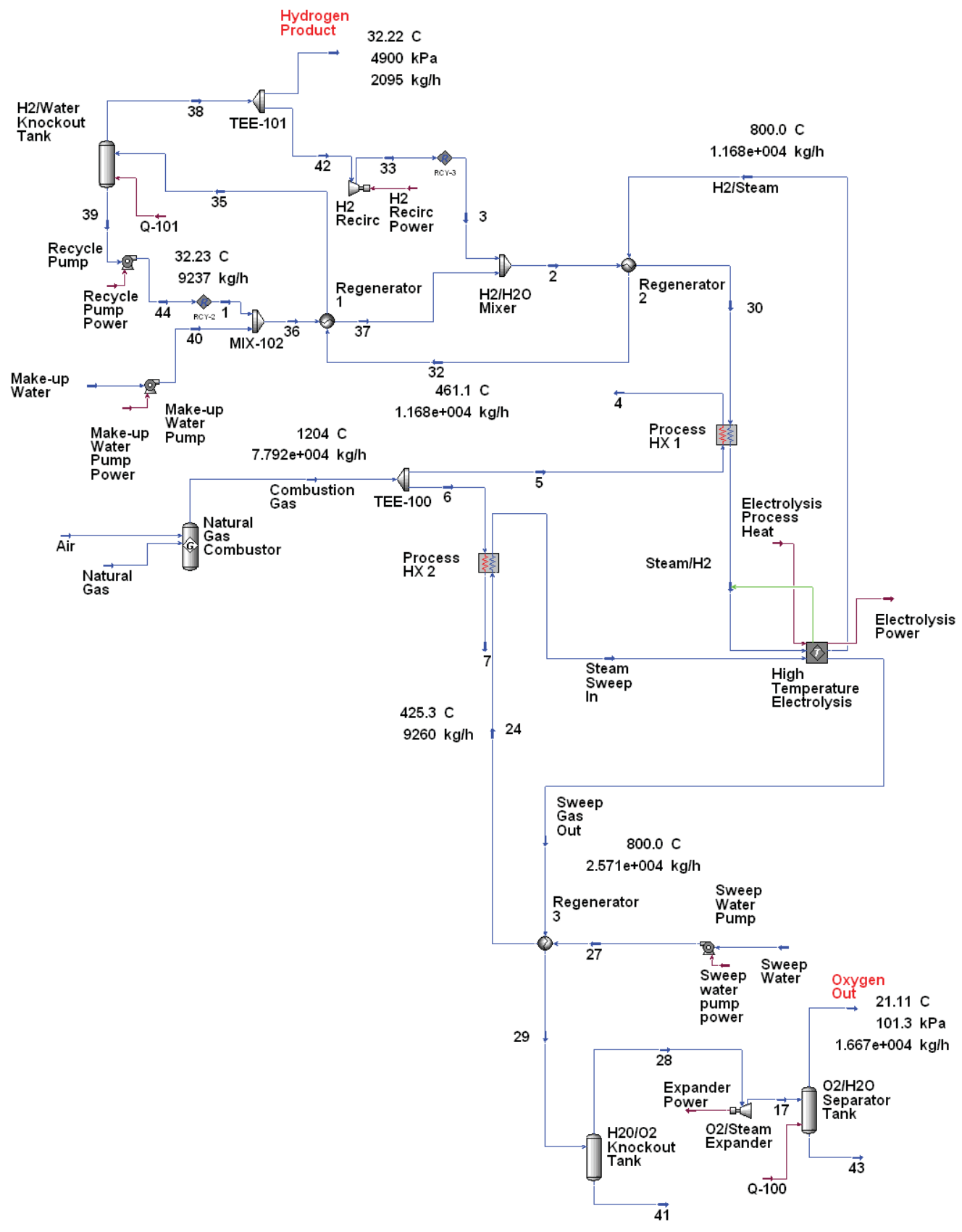

Figure 1. Process flow diagram for reference $50,000 \mathrm{~kg} / \mathrm{day}$ hydrogen production plant.

The process flow diagram in Figure 1 also shows the steam sweep system used to remove the excess oxygen that is evolved on the anode side of the electrolyzer. The feed water is supplied to the steam sweep system and raised to the process operating pressure in the liquid phase by the Sweep Water pump (shown in the lower right portion of the flow diagram). This water is converted to steam in Regenerator 3 and then passed through the natural gas-fired heater (Process HX 2) where it is heated to the electrolysis operating temperature of $800^{\circ} \mathrm{C}$. The sweep steam then passes through the electrolyzer, taking with it the oxygen that has evolved on the anode side.
The resulting steam/oxygen mixture (approximately 50\% oxygen) is then cooled and partially condensed by passing back through Regenerator 3. The steam and oxygen mixture then passes through the $\mathrm{H} 2 \mathrm{O} / \mathrm{O} 2$ Knockout Tank where the condensate (approximately $20 \%$ of the moisture content) is removed before entering the O2/Steam Expander. The electric power produced in the expansion process is slightly higher than the total pumping requirements of the combined process and steam sweep loops. As a result, for this system configuration, the net electric power requirement for the total system is slightly less than the required electrical power of the 
electrolyzer alone. After leaving the expander, the remaining steam and oxygen mixture enters the $\mathrm{O} 2 / \mathrm{H} 2 \mathrm{O}$ Separator tank where the majority of any residual steam is condensed and separated, yielding dry oxygen byproduct.

The natural gas-fired heaters used in the HYSYS analysis were modeled assuming a Gibbs reaction model (Natural Gas Combustor) shown in the lower left portion of the process flow diagram. Since this model assumes stoichiometric conditions for the combustion process, the ratio of air and natural gas flow rates was adjusted to give the desired combustion gas temperature of $2200^{\circ} \mathrm{F}\left(1204^{\circ} \mathrm{C}\right)$. The combined air and natural gas flow rate was then adjusted to provide the needed process heat to raise both the inlet steam/hydrogen process stream and sweep gas stream to the electrolyzer operating temperature $\left(800^{\circ} \mathrm{C}\right)$. Optimization of the two process heaters (Process HX 1 and Process HX 2) was achieved by controlling the distribution of the combustion gas stream delivered to each of the process heaters (at TEE-100). For the reference design, the optimum distribution (assuming a minimum approach temperature of $25^{\circ} \mathrm{C}$ for each of the process heaters) resulted in approximately $89 \%$ of the combustion gas delivered to Process HX 1 and $11 \%$ to Process HX 2.

\section{RESULTS OF REFERENCE PLANT PROCESS ANALYSIS}

Figure 1 shows values of fluid conditions (temperature, pressure and mass flow rate) at various state points around the system. As noted earlier, the electrolyzer was operated in the thermal-neutral mode. A total of 350,000 electrolysis cells were required, each with an active cell area of $225 \mathrm{~cm}^{2}$. The cells were operated at a current density of $0.699 \mathrm{amps} / \mathrm{cm}^{2}$, with an area specific resistance of $0.2776 \mathrm{ohms}-\mathrm{cm}^{2}$ producing approximately $50,000 \mathrm{~kg} /$ day $(2,095 \mathrm{~kg} / \mathrm{hr})$ of hydrogen at an operating temperature of $800^{\circ} \mathrm{C}$. The resulting electrolyzer efficiency (based on the lower heating value of hydrogen) is defined as:

$\eta(E)=\frac{L H V * m(H 2) * 100}{P(E)}$

where

$\eta(E)=$ electrolyzer hydrogen production efficiency (\%),

$\mathrm{LHV}^{*} \mathrm{~m}(\mathrm{H} 2)=$ energy content of hydrogen product gas based on lower heating value,

$\mathrm{P}(\mathrm{E})=$ electrical power input to electrolyzer $(\mathrm{kW})$, was calculated to be $97.5 \%$.

The overall facility hydrogen production efficiency, defined as:

$$
\begin{aligned}
& \eta(S)=\frac{L H V * m(H 2) * 100}{\sum P(\text { pumps })+P(\operatorname{circ})-P(\text { expand })+P(E)+L H V * m(N G)} \\
& \text { where } \\
& \eta(\mathrm{S})=\text { facility hydrogen production efficiency, }
\end{aligned}
$$

$\sum \mathrm{P}($ pumps $)=$ electric power input to all pumps in the system $(\mathrm{kW})$,

$\mathrm{P}($ circ $)=$ electric power input to helium circulator $(\mathrm{kW})$,

$\mathrm{P}($ expand $)=$ electric power produced by the O2/Steam Expander,

$\mathrm{LHV}^{*} \mathrm{~m}(\mathrm{NG})=$ energy content of natural gas feed based on lower heating value $(\mathrm{kW})$, was calculated to be $69.4 \%$.

As noted earlier, the relatively high overall system hydrogen production efficiency was in part achieved because the O2/Steam Expander produced more power than was required to drive the other components in the process and steam sweep loops. As a result, the steam expander power recovery contributed about $3 \%$ of the electric power required for the electrolysis process, resulting in a fractional reduction in the electric power supplied from the grid.

\section{ECONOMIC ASSUMPTIONS FOR REFERENCE PLANT DESIGN}

As part of the H2A economic analysis methodology, a set of common cost assumptions were developed and incorporated into the analysis spreadsheet. The common cost assumptions were intended to be applied for all H2A supply options, but analysts can vary these assumptions to test the sensitivity of costs to the most critical assumptions. The set of base case assumptions used in the H2A methodology are:

- Analysis Methodology — Discounted Cash Flow (DCF) model that calculates a levelized $\mathrm{H} 2$ price that yields a prescribed internal rate of return (IRR)

- Reference Financial Structure - 100\% equity with $10 \%$ IRR - Include levelized H2 price plot for 0 to $25 \%$ IRR - Model allows debt financing

- Reference Year Dollars - adjusted at half-decade increments (e.g., 2005, 2010)

- Technology Development Stage - All cost estimates are based on mature, commercial facilities

- Inflation Rate - $1.9 \%$, but with resultant price of $\mathrm{H} 2$ in reference year constant dollars

- Income Taxes - 35\% Federal; 6\% State; 38.9\% Effective Property Taxes and Business Insurance - 2\%/year of the total initial capital cost

- Sales Tax - Not included on basis that facilities and related purchases are wholesale and through a general contractor entity

- Working Capital Rate - $15 \%$ of the annual change in the total operating costs

- Analysis Period - 40 years

- Facility Life - 40 years

- Depreciation Type and Schedule for Initial Depreciable Capital Cost - MACRS - 20 years

- Construction Period and Cash Flow — Varies per case

- Planned Replacement Capital - Post startup capital costs spread over time based on specific replacement estimates. 
Depreciation is based on MACRS schedule and 7 years or the same as the replacement period if it is shorter than 7 years.

- Unplanned Replacement Capital — Specified percentage of initial depreciable capital cost meant to handle unplanned replacement capital expenses that occur during an operating year of the plant. Depreciation is based on MACRS schedule and 7 years.

- Project Contingency — \% adjustment to the total initial capital cost such that the result represents the mean or expected cost value. Periodic replacement capital includes project contingency.

- Process Contingency — \% adjustment to the total initial capital cost such that the result incorporates the mean or expected overall performance.

- Land Cost — \$5000/acre

- Capacity Factor - 90\% for Central, with case exceptions

- Average Burdened Labor Rate for Staff — \$50/hour

- G\&A Rate - $20 \%$ of the staff labor costs above

- $\mathrm{CO}_{2}$ incentive (when $\mathrm{CO}_{2}$ sequestration is not plausible) not included in Base cases, sensitivity included at \$100/tonne $\mathrm{C}\left(\$ 27.3 /\right.$ tonne $\left.\mathrm{CO}_{2}\right)$

- $\mathrm{O}_{2}$ Credit - Not included in Base cases, sensitivity included at $\$ 20 /$ tonne

- Salvage Value - 10\% of initial capital, with case exceptions

- Decommissioning - 10\% of initial capital, with case exceptions

- Hydrogen Pressure at Central Gate - 300 psig. If higher pressure is inherent to the process, apply pumping power credit for pressure $>300$ psig.

- Central Storage - Buffer only as required for efficient operations

- Hydrogen Purity — 98\% minimum; CO < 10ppm, sulfur $<$ $10 \mathrm{ppm}$

- Sensitivity Variables and Ranges - Based on applying best judgment of $10 \%$ and $90 \%$ confidence limit extremes to the most significant baseline cost and performance parameters

The above assumptions along with basic process information calculated using the HYSYS model described earlier were input to the $\mathrm{H} 2 \mathrm{~A}$ spreadsheet to calculate the lifecycle cost for the reference $50,000 \mathrm{~kg} /$ day hydrogen production plant design. The input to the spreadsheet and calculated lifecycle costs are described in more detail in the next two sections.

\section{INPUT TO H2A LIFECYCLE ANALYSIS}

The financial information used in the spreadsheet was primarily based on the $\mathrm{H} 2 \mathrm{~A}$ assumptions described in the above section, but in this case, the assumed plant capacity factor was $95 \%$ based on the relatively simple design and assumed reliability of the SOE modules. Plant-specific financial input included information on the construction time, plant startup date, capital expenditure rate during construction, and revenue
Table 1. Financial assumptions for $50,000 \mathrm{~kg} /$ day hydrogen production plant.

\begin{tabular}{|c|c|}
\hline Reference year & 2010 \\
\hline Assumed start-up year & 2020 \\
\hline Length of Construction Period (years) & 2 \\
\hline $\begin{array}{l}\% \text { of Capital Spent in } 1 \text { st Year of } \\
\text { Construction }\end{array}$ & $60 \%$ \\
\hline $\begin{array}{l}\% \text { of Capital Spent in 2nd Year of } \\
\text { Construction }\end{array}$ & $40 \%$ \\
\hline $\begin{array}{l}\% \text { of Capital Spent in 3rd Year of } \\
\text { Construction }\end{array}$ & $0 \%$ \\
\hline $\begin{array}{l}\% \text { of Capital Spent in 4th Year of } \\
\text { Construction }\end{array}$ & $0 \%$ \\
\hline Start-up Time (years) & 1 \\
\hline Plant life (years) & 40 \\
\hline Analysis period (years) & 40 \\
\hline Depreciation Schedule Length (years) & 7 \\
\hline Depreciation Type & MACRS \\
\hline$\%$ Equity Financing & $100 \%$ \\
\hline Interest rate on debt, if applicable (\%) & $3.50 \%$ \\
\hline Debt period (years) & 40 \\
\hline $\begin{array}{l}\% \text { of Fixed Operating Costs During Start- } \\
\text { up }(\%)\end{array}$ & $100 \%$ \\
\hline$\%$ of Revenues During Start-up (\%) & $75 \%$ \\
\hline $\begin{array}{l}\% \text { of Variable Operating Costs During } \\
\text { Start-up }(\%)\end{array}$ & $75 \%$ \\
\hline $\begin{array}{l}\text { Decommissioning costs (\% of depreciable } \\
\text { capital investment) }\end{array}$ & $10 \%$ \\
\hline $\begin{array}{l}\text { Salvage value }(\% \text { of total capital } \\
\text { investment })\end{array}$ & $10 \%$ \\
\hline Inflation rate $(\%)$ & $1.9 \%$ \\
\hline After-tax Real IRR (\%) & $10.0 \%$ \\
\hline State Taxes $(\%)$ & $6.0 \%$ \\
\hline Federal Taxes $(\%)$ & $35.0 \%$ \\
\hline Total Tax Rate $(\%)$ & $38.90 \%$ \\
\hline $\begin{array}{l}\text { WORKING CAPITAL ( } \% \text { of yearly change } \\
\text { in operating costs) }\end{array}$ & $15 \%$ \\
\hline
\end{tabular}

and operating costs during startup are shown in Table 1. Table 1 also shows selected financial input values used in the analysis of the $50,000 \mathrm{~kg} /$ day HTE reference central plant design. Most of the financial input uses the recommended guidelines of the H2A methodology discussed in the previous section. The startup date is 2020 with an assumed 2 year construction period.

Plant capital cost information input by the user includes uninstalled and installed system and equipment costs, indirect depreciable capital costs (including site preparation, engineering and design, licensing and permitting, and associated contingencies), and non-depreciable capital costs (primarily the cost of the land for the plant site). 
Table 2. Reference 50,000 kg/day direct depreciable capital costs.

\begin{tabular}{|c|c|c|c|c|}
\hline $\begin{array}{r}\text { Major pieces/systems of } \\
\text { equipment }\end{array}$ & $\begin{array}{c}\text { Baseline } \\
\text { Uninstalled Costs }\end{array}$ & $\begin{array}{c}\text { Installation Cost } \\
\text { Factor }\end{array}$ & $\begin{array}{l}\text { Baseline Installed } \\
\text { Costs }\end{array}$ & Data Source \\
\hline Water Supply System & $\$ 249,802$ & 1.20 & $\$ 299,762$ & Reference 10. \\
\hline Make-Up Water Pump & $\$ 60,100$ & 4.11 & $\$ 247,011$ & Reference 6. \\
\hline H2/Water Separation Tank & $\$ 67,950$ & 4.11 & $\$ 279,275$ & Reference 6. \\
\hline Recycle Water Pump & $\$ 8,900$ & 4.11 & $\$ 36,579$ & Reference 6. \\
\hline Regenerator 1 & $\$ 217,600$ & 4.11 & $\$ 894,336$ & References 6 and 7. \\
\hline Regenerator 2 & $\$ 143,600$ & 4.11 & $\$ 590,196$ & References 6 and 7. \\
\hline Regenerator 3 & $\$ 583,200$ & 4.11 & $\$ 2,396,952$ & References 6 and 7. \\
\hline $\mathrm{H} 2 \mathrm{O} / \mathrm{O} 2$ Knockout Tank & $\$ 67,950$ & 4.11 & $\$ 279,275$ & Reference 6. \\
\hline O2/H2O Separator Tank & $\$ 45,300$ & 4.11 & $\$ 186,183$ & Reference 6. \\
\hline O2/Steam Expander & $\$ 813,850$ & 1.35 & $\$ 1,098,698$ & Reference 8. \\
\hline Sweep Water Pump & $\$ 41,700$ & 4.11 & $\$ 171,387$ & Reference 6. \\
\hline H2 Recirculator & $\$ 12,298$ & 4.11 & $\$ 50,545$ & INL estimate \\
\hline $\begin{array}{lll}\text { Natural } & \text { Gas-Fired } & \text { Process } \\
\text { Heater 1 } & & \\
\end{array}$ & $\$ 948,631$ & 4.11 & $\$ 3,898,873$ & Reference 9, Pg. 121 \\
\hline $\begin{array}{lll}\text { Natural } & \text { Gas-Fired } & \text { Process } \\
\text { Heater 2 } & & \\
\end{array}$ & $\$ 166,010$ & 4.11 & $\$ 682,301$ & Reference 9, Pg. 121 \\
\hline $\begin{array}{l}\text { HTE Piping, Electrical } \\
\text { Equipment (including AC/DC } \\
\text { conversion), Misc. HTE plant } \\
\text { Equipment }\end{array}$ & $\$ 993,415$ & 1.20 & $\$ 1,192,098$ & $\begin{array}{l}\text { Transf/Rect Unit cost } \\
\text { Reference } 4 . \text { Other misc. } \\
\text { mechanical and electrical } \\
\text { from References } 5 \text { and } \\
11 .\end{array}$ \\
\hline $\begin{array}{l}\text { Solid Oxide Electrolyzer (SOE) } \\
\text { Modules }\end{array}$ & $\$ 3,544,500$ & 1.80 & $\$ 6,380,100$ & INL/Cerametec Estimate \\
\hline TOTALS & $\$ 7,964,806$ & & $\$ 18,683,570$ & \\
\hline
\end{tabular}

The system and equipment capital cost information for the $50,000 \mathrm{~kg} /$ day central hydrogen production plan is summarized in Table 2. Uninstalled system and equipment costs were obtained from the references provided under "Data Source" in Column 5 of the table. For the most part, an installation factor of 4.11 was used to calculate installed equipment costs (Column 4) except as noted. For example, the installation cost factor for the Solid Oxide Electrolyzer (SOE) modules was assumed to be 1.8 since it is expected that the future design of these modules will be relatively simple and compact, allowing easy turnkey installation of multiple modules without significant installation costs. In effect, the 1.8 multiplier represents the cost of the completely assembled SOE module brought to the sight and installed in a plug-in fashion at minimal cost. The total installed cost of plant equipment obtained by summing the costs in Column 4 is $\$ 18,683,570$. This represents the total depreciable direct capital investment.

In addition to the above direct depreciable capital costs for the hydrogen production plant, the $\mathrm{H} 2 \mathrm{~A}$ central plant spreadsheet also calculates the capital cost for carbon sequestration (pipeline, injection wells, compressors, etc.) using a standard set of analysis assumptions, and information obtained from HYSYS on the amount of carbon dioxide $\left(\mathrm{CO}_{2}\right)$ produced by the natural gas combustion process shown in Figure 1. The calculated total direct capital costs for carbon sequestration for the large central hydrogen production plant producing $50,000 \mathrm{~kg} /$ day of hydrogen was $\$ 32,690,093$.

Indirect depreciable capital costs for the large central hydrogen production plant are summarized in Table 3. These costs include site preparation, engineering and design work, contingency costs, and up-front permitting costs. As indicated in the table, these costs were either estimated or assumed to be a percentage of the total direct depreciable hydrogen plant costs. The total calculated indirect depreciable costs in Table 3 are $\$ 7,636,593$, and when added to the total hydrogen plant direct depreciable costs from Table $2(\$ 18,683,570)$ gives total depreciable costs without carbon sequestration of $\$ 26,320,163$. If total direct capital costs for carbon sequestration ( $\$ 32$, 690,093), are added to the plant depreciable costs, the total depreciable costs for the $50,000 \mathrm{~kg}$ /day HTE central plant design with carbon sequestration is $\$ 59,010,256$.

The only non-depreciable cost for the large central hydrogen production plant was the cost of land required for the plant site. In this case, it was assumed that 5 acres of land would be required at a cost of $\$ 5,000 /$ acre, for a total nondepreciable cost of $\$ 25,000$. When this cost was added to the depreciable costs, the total capital cost for the large central hydrogen production plant was $\$ 59,035,256$. 
Table 3. Reference plant indirect depreciable costs.

\begin{tabular}{|l|l|}
\hline $\begin{array}{l}\text { Site Preparation (\$), 1\% of direct capital } \\
\text { costs }\end{array}$ & $\$ 186,836$ \\
\hline $\begin{array}{l}\text { Engineering \& design (\$), 8\% of direct } \\
\text { capital costs }\end{array}$ & $\$ 1,494,686$ \\
\hline $\begin{array}{l}\text { Project contingency (\$), 30\% of direct } \\
\text { capital costs }\end{array}$ & $\$ 5,605,071$ \\
\hline Up-Front Permitting Costs (\$), Estimated & $\$ 350,000$ \\
\hline Total Indirect Depreciable Capital Costs & $\$ 7,636,593$ \\
\hline
\end{tabular}

Additional costs to be considered in this large central hydrogen production plant lifecycle analysis are the fixed and variable yearly operating costs. The fixed operating costs include burdened labor, taxes and insurance, and material costs for maintenance and repairs. These costs are summarized in Table 4. The total fixed operating costs, shown at the bottom of the second column in Table 4, amount to $\$ 6,178.705$

In addition to the fixed operating costs summarized in Table 4, there are also variable production costs to be considered. These variable production costs include energy feedstock and utility costs, and other feedstock costs; all of which can be partially offset by income from any saleable byproduct of the hydrogen production process. For the large central hydrogen production plant, the energy feedstock is the industrial natural gas used by the natural gas fired-heaters for process heat, and the energy utility is the required grid industrial electricity used by the electrolysis process and to drive the process system components (pumps, compressors, etc.). Table 5 summarizes the energy feedstock and utility usage per kilogram of hydrogen produced (based on HYSYS

Table 4. Fixed operating costs for reference hydrogen production plant.

\begin{tabular}{|l|r|}
\hline $\begin{array}{l}\text { Total plant staff (number of FTEs } \\
\text { employed by plant) }\end{array}$ & 10 \\
\hline $\begin{array}{l}\text { Burdened labor cost, including overhead } \\
\text { (\$/man-hr) }\end{array}$ & $\$ 50.00$ \\
\hline Labor cost, \$/year & $\$ 1,040,000$ \\
\hline $\begin{array}{l}\text { General and Administrative (G\&A) rate } \% \\
\text { of labor cost) }\end{array}$ & $20 \%$ \\
\hline G\&A (\$/year) & $\$ 208,000$ \\
\hline Licensing, Permits and Fees (\$/year) & $\$ 0.00$ \\
\hline $\begin{array}{l}\text { Property tax and insurance rate }(\% \text { of total } \\
\text { capital investment) }\end{array}$ & $\$ 1,180,705$ \\
\hline Property taxes and insurance (\$/year) & $\$ 3,750,000$ \\
\hline $\begin{array}{l}\text { Material costs for maintenance and repairs } \\
\text { (\$/year) }\end{array}$ & $\$ 6,178,705$ \\
\hline Total Fixed Operating Costs &
\end{tabular}

Table 5. Variable reference plant operating energy feedstock and utility requirements and costs.

\begin{tabular}{|c|c|c|c|}
\hline Feedstock & $\begin{array}{c}\text { Price in } \\
\text { Startup Year } \\
\mathbf{( \$ 2 0 1 0 ) / N m 3}\end{array}$ & $\begin{array}{c}\text { Usage } \\
\mathbf{( N m 3 / k g} \\
\mathbf{H 2})\end{array}$ & $\begin{array}{c}\text { Cost in } \\
\text { Startup Year }\end{array}$ \\
\hline $\begin{array}{c}\text { Industrial } \\
\text { Natural Gas }\end{array}$ & 0.21 & 1.47 & $\$ 5,488,858$ \\
\hline & & & \\
\hline Utility & $\begin{array}{c}\text { Price in } \\
\text { Startup Year } \\
\mathbf{( \$ 2 0 1 0 ) / k W h}\end{array}$ & $\begin{array}{c}\text { Usage } \\
\mathbf{( k W h / k g} \\
\mathbf{H 2})\end{array}$ & $\begin{array}{c}\text { Cost in } \\
\text { Startup Year }\end{array}$ \\
\hline Industrial & 0.06 & 32.85 & $\$ 32,412,960$ \\
Electricity & & & \\
\hline
\end{tabular}

analysis), and the resulting variable cost in the startup year (2020) based on H2A default unit energy costs (shown in Column 2 of the table).

The other remaining variable cost is for demineralized water used to replace the water used in the electrolysis process, and to make up for the small amount of water that is not recovered from the hydrogen and oxygen product streams. Table 6 shows the cost of the demineralized water, the water used per kilogram of hydrogen produced (based on results from HYSYS), and the cost of the demineralized water feed in the startup year (2020).

Also shown in Table 6 is the value of the oxygen byproduct generated in the electrolysis process, the amount of oxygen generated per kilogram of hydrogen produced (from HYSYS), and the income generated in the startup year from the production of the oxygen. As noted earlier, in the lifecycle analysis the demineralized water usage represents a variable cost for the production process, and the oxygen byproduct represents variable income.

The resulting total feedstock and utility costs, and byproduct credits in startup year 2020 are shown in Table 7 for an assumed total yearly hydrogen production rate of $17,434,590$ $\mathrm{kg}$. The total energy feedstock cost is the yearly cost of the industrial natural gas used for process heat. The total utility cost is the yearly cost of the grid supplied industrial electricity; the total non-energy cost is the yearly cost of demineralized

Table 6. Other reference plant feed and byproduct costs/income.

\begin{tabular}{|c|c|c|c|}
\hline Feed/utility & $\begin{array}{c}\mathbf{\$ ( 2 0 0 5 ) / g a} \\
\text { l }\end{array}$ & $\begin{array}{c}\text { Usage per } \\
\mathbf{k g ~ H 2} \\
\text { (gal) }\end{array}$ & $\begin{array}{c}\text { Cost in } \\
\text { Startup } \\
\text { Year }\end{array}$ \\
\hline $\begin{array}{c}\text { Demineralized } \\
\text { Water }\end{array}$ & 0.005 & 2.33 & $\$ 207,667$ \\
\hline Byproduct & $\$(\mathbf{2 0 0 5 ) / k g}$ & $\begin{array}{c}\text { Productio } \\
\mathbf{n ~ p e r ~ k g} \\
\mathbf{H 2} \mathbf{( k g})\end{array}$ & $\begin{array}{c}\text { Income in } \\
\text { Startup } \\
\text { Year }\end{array}$ \\
\hline Oxygen & 0.02 & 7.76 & $\$ 2,763,846$ \\
\hline
\end{tabular}


Table 7. Total feed, utility, and byproduct variable costs for reference plant design.

\begin{tabular}{|l|r|}
\hline $\begin{array}{l}\text { Total Non-Energy Feedstock Costs } \\
\text { (\$/year), Demin. Water }\end{array}$ & $\$ 207,667$ \\
\hline $\begin{array}{l}\text { Total Energy Feedstock Costs (\$/year), } \\
\text { Ind. Natural Gas }\end{array}$ & $\$ 5,488,858$ \\
\hline $\begin{array}{l}\text { Total Utility Costs (\$/year), Industrial } \\
\text { Electricity }\end{array}$ & $\$ 32,620,627$ \\
\hline $\begin{array}{l}\text { Total Byproduct Credits (\$/year), } \\
\text { Oxygen }\end{array}$ & $(\$ 2,763,846)$ \\
\hline $\begin{array}{l}\text { Other variable operating costs (e.g. } \\
\text { environ. surcharges, mat., waste } \\
\text { treatment/disposal,) (\$year) }\end{array}$ & $\$ 400,000$ \\
\hline $\begin{array}{l}\text { CO } \mathbf{2} \text { Sequestration O\&M costs and } \\
\text { credits (\$/year) }\end{array}$ & $\$ 932,304$ \\
\hline Total Variable Operating Costs (\$/year) & $\$ 36,677,943$ \\
\hline
\end{tabular}

water used in the hydrogen production process; and the total byproduct credits represents the income from the yearly production of oxygen. The resulting total variable operating costs (including credit for the oxygen byproduct is of $\$ 36,677,943$.

The remaining costs include SOE replacement costs, and other unplanned replacement costs. Because of the relatively simple and compact reference hydrogen production plant design, unplanned replacement costs were assumed to be $2 \%$ of the total depreciable (direct and indirect) capital costs/year, or $\$ 1,180,205 / \mathrm{yr}$ in $(2010 \$)$. For the SOE module replacement costs, it was assumed that $1 / 5$ of the SOE cells would be replaced each year (begin in 2020), and that only the cost of the SOE cells $(\$ 50 / \mathrm{kW})$ would be considered, since the remaining module components (vessels, headers, etc.) would not be replaced. The resulting SOE replace cost would be $\$ 708,900 /$ year $(2010 \$)$.

With the above plant operating assumptions and financial information, the H2A spreadsheet performed a lifecycle cost analysis to predict hydrogen production costs with and without carbon sequestration, as discussed in the following section.

\section{RESULTS OF LIFECYCLE ANALYSIS OF REFERECE 50,000 KG/DAY HYDROGEN PRODUCTION PLANT}

The results of the H2A lifecycle cost analysis include a cash flow analysis for the plant construction and startup periods, and for the operating life of the plant. The resulting hydrogen production cost was determined based on the plant hydrogen-production capacity with and without carbon sequestration, and assuming an after-tax internal rate of return (IRR) of $10 \%$. The resulting cost components and total hydrogen production cost without carbon sequestration are summarized in Table 8.

To achieve an after-tax internal rate of return of $10 \%$ the required hydrogen price calculated using the $\mathrm{H} 2 \mathrm{~A}$ spreadsheet methodology is $\$ 2.68 / \mathrm{kg}$. This represents the price or cost of the hydrogen leaving the plant gate at $5 \mathrm{MPa}$ pressure. The
Table 8. Hydrogen production cost summary for reference plant without carbon sequestration.

\begin{tabular}{|r|c|r|}
\hline Specific Item Cost Calculation \\
\hline Cost Component & $\begin{array}{c}\text { Cost } \\
\text { Contribution } \\
\mathbf{( \$ / k g )}\end{array}$ & $\begin{array}{c}\text { Percentage of } \\
\text { H2 Cost }\end{array}$ \\
\hline Capital Costs & $\$ 0.34$ & $12.5 \%$ \\
\hline Fixed O\&M & $\$ 0.32$ & $12.1 \%$ \\
\hline Feedstock Costs & $\$ 0.33$ & $12.3 \%$ \\
\hline $\begin{array}{r}\text { Other Raw Material } \\
\text { Costs }\end{array}$ & $\$ 0.01$ & $0.4 \%$ \\
\hline Byproduct Credits & $-\$ 0.16$ & $-5.8 \%$ \\
\hline $\begin{array}{r}\text { Other Variable Costs } \\
\text { (including utilities) }\end{array}$ & $\$ 1.84$ & $68.5 \%$ \\
\hline Total & $\$ 2.68$ & \\
\hline
\end{tabular}

major cost component was other variable costs, which is the cost of the industrial grid electricity used in the hydrogen production process, representing $68.5 \%$ of the total hydrogen production cost. Capital costs were $12.5 \%$ of total costs followed by feedstock costs (natural gas) and fixed O\&M costs, representing $12.3 \%$ and $12.1 \%$ of the total hydrogen production cost, respectively. The demineralized water (raw material) made up the remaining $0.4 \%$ of total hydrogen production costs. These costs were partially offset by the value of the oxygen byproduct produced in the HTE process, which reduced the hydrogen production costs by $\$ 0.16 / \mathrm{kg}$.

If carbon sequestration is included in the $\mathrm{H} 2 \mathrm{~A}$ analysis, additional capital, O\&M and energy costs associated with the carbon sequestration process must be added to the total hydrogen costs. These approximate additional costs represent the cost of the sequestration process $\left(\mathrm{CO}_{2}\right.$ pipelines, injection well(s), compressors, etc.), but do not include carbon capture capital and operating costs. The costs associated with the carbon sequestration process are summarized in Table 9. The major cost component in this case is the capital costs, which as noted earlier, amount to $\$ 32,690,093$ or $78 \%$ of the total cost per ton of $\mathrm{CO}_{2}$ sequestered (Table 9).

When the above carbon sequestration costs are added to the hydrogen production costs, the resulting total hydrogen production cost and cost components are shown in Table 10 . Total hydrogen production cost with carbon sequestration is $\$ 3.08 / \mathrm{kg}$. Variable costs, which include utility costs, again represent the largest cost component at $\$ 1.91 / \mathrm{kg}$ or $61.8 \%$ of the total cost of hydrogen production. Capital costs are again the second largest cost component, and are higher because they include the capital cost of the carbon sequestration equipment. Fixed O\&M and feedstock costs represent $11.8 \%$ and $10.7 \%$ of total costs, respective; followed by raw material costs at $0.4 \%$ of total costs. 
Table 9. Summary of carbon sequestration cost for reference plant.

\begin{tabular}{|l|l|l|}
\hline \multicolumn{3}{|c|}{ Approximate Carbon Sequestration Costs* } \\
\hline Cost Component & $\begin{array}{l}\text { Cost } \\
\text { Contribution } \\
\text { (\$/ kg H2) }\end{array}$ & $\begin{array}{l}\text { Cost Contribution } \\
\text { (\$/ tonne CO2 } \\
\text { Sequestered) }\end{array}$ \\
\hline Capital Costs & $\$ 0.25$ & $\$ 91.40$ \\
\hline O\&M Cost & $\$ 0.05$ & $\$ 19.60$ \\
\hline Energy Cost & $\$ 0.02$ & $\$ 5.70$ \\
\hline Total & $\$ 0.32$ & $\$ 116.70$ \\
\hline $\begin{array}{l}* \text { Carbon sequestration costs presented in this table do not } \\
\text { include carbon capture capital and operating costs. }\end{array}$ \\
\hline
\end{tabular}

\section{SENSITIVITY STUDY}

A sensitivity analysis was performed to evaluate the impact of various economic assumptions on hydrogen lifecycle production costs. The results of this analysis are summarized in the tornado plot in Figure 2, which shows the sensitivity of hydrogen production costs to the various economic and operational assumptions used in the $\mathrm{H} 2 \mathrm{~A}$ economic analysis of the reference HTE plant. The tornado plot shows the impact on hydrogen production cost when a single variable is changed while holding other variables constant. In the tornado plot, the parameters that have the largest impact on production costs are shown at the top, and the parameters that have the least impact on hydrogen production costs are shown at the bottom. Therefore, the importance of parameters on hydrogen production costs decreases as the plot is read from top to bottom. As indicated in the plot, the cost of grid industrial

Table 10. Hydrogen production cost summary for reference plant with carbon sequestration.

\section{Specific Item Cost Calculation}

\begin{tabular}{|c|c|c|}
\hline Cost Component & $\begin{array}{c}\text { Cost } \\
\text { Contribution } \\
\mathbf{( \$ / k g )}\end{array}$ & $\begin{array}{c}\text { Percentage of H2 } \\
\text { Cost }\end{array}$ \\
\hline Capital Costs & $\$ 0.63$ & $20.4 \%$ \\
\hline Fixed O\&M & $\$ 0.36$ & $11.8 \%$ \\
\hline Feedstock Costs & $\$ 0.33$ & $10.7 \%$ \\
\hline $\begin{array}{c}\text { Other Raw Material } \\
\text { Costs }\end{array}$ & $\$ 0.01$ & $0.4 \%$ \\
\hline Byproduct Credits & $-\$ 0.16$ & $-5.0 \%$ \\
\hline $\begin{array}{c}\text { Other Variable Costs } \\
\text { (including utilities) }\end{array}$ & $\$ 1.91$ & $61.8 \%$ \\
\hline Total & $\$ \mathbf{3 . 0 8}$ & \\
\hline
\end{tabular}

electricity has the greatest impact on hydrogen production costs. When the cost of electricity is varied by minus or plus $20 \%$, hydrogen production costs vary between $\$ 2.31 / \mathrm{kg}$ to $\$ 3.06 / \mathrm{kg}$ of hydrogen produced. The after-tax internal rate of return is next in importance. When the after-tax internal rate of return is varied from its initial value of $10 \%$ to a minimum value of $5 \%$ and a maximum value of $15 \%$, the hydrogen production costs change from the reference value of $\$ 2.68 / \mathrm{kg}$ to a minimum value of $\$ 2.56 / \mathrm{kg}$ and a maximum value of $\$ 2.83 / \mathrm{kg}$. The third most important parameter is the cost of the industrial natural gas used for process heat. When the cost of natural gas is varied by minus or plus $20 \%$, the hydrogen production cost varies between $\$ 2.65 / \mathrm{kg}$ and $\$ 2.72 / \mathrm{kg}$, respectively. Variations in the remaining parameters shown in Figure 2 (total direct capital cost, required labor, and operating capacity factor) all appear to have only moderate influences on the cost of hydrogen production.

\section{CONCLUSIONS}

Detailed results of system evaluation and lifecycle cost analyses performed for a commercial-scale $50,000 \mathrm{~kg} /$ day hightemperature electrolysis hydrogen production plant were presented. The reference plant design used natural gas-fired heaters to supply process heat and grid electricity to power the electrolysis process and system components. The design was optimized using the HYSYS process analysis software that includes realistic representations of fluid conditions and component efficiencies and operating parameters throughout the system. The detailed results of the HYSYS analyses were then used as input to the H2A lifecycle cost analysis for largescale hydrogen production $(50,000 \mathrm{~kg} /$ day $)$ with and without carbon sequestration. The $50,000 \mathrm{~kg} /$ day reference central hydrogen production plant was able to produce hydrogen at a cost of only $\$ 2.68 / \mathrm{kg}$ without considering the cost of carbon sequestration. When the cost of carbon sequestration is included, the production cost of hydrogen for the $50,000 \mathrm{~kg} / \mathrm{day}$ central hydrogen production plant increased to $\$ 3.08 / \mathrm{kg}$.

Sensitivity calculations were also performed by individually varying various economic and operating assumptions while keeping other parameters constant. Results of these sensitivity calculations showed that the cost of grid industrial electricity had the greatest impact on hydrogen production costs. The after-tax internal rate of return had the second greatest impact on hydrogen production costs, followed by the cost of industrial natural gas used for process heat, which had the third greatest impact on hydrogen production costs. Variations in other parameters (including total direct capital cost, required labor, and operating capacity factor) all appeared to have only moderate influence on the cost of hydrogen production.

\section{ACKNOWLEDGMENTS}

This work was supported by the U.S. Department of Energy, Office of Nuclear Energy, Next Generation Nuclear Plant project. 


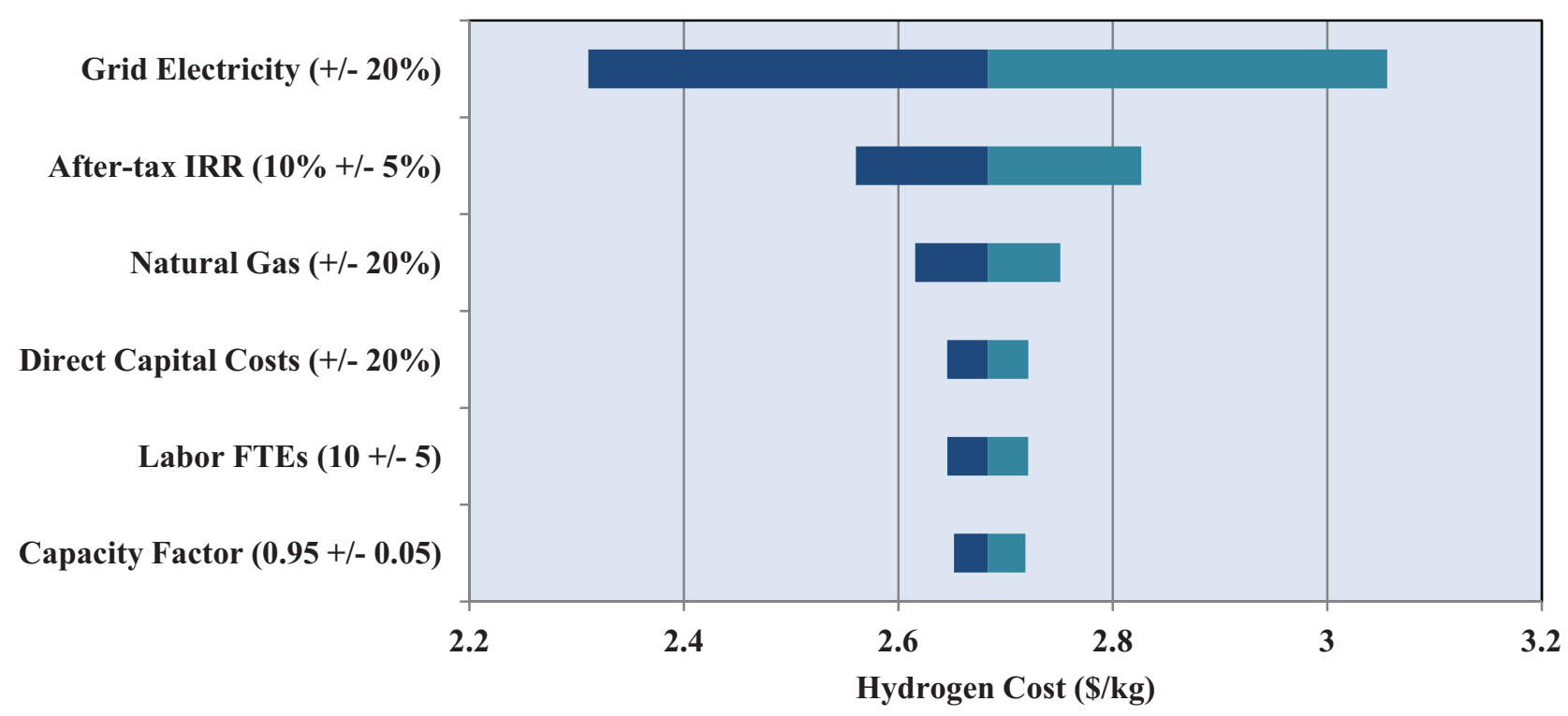

Figure 2.Tornado plot showing sensitivity of hydrogen cost to parameter variations.

\section{COPYRIGHT STATEMENT}

This manuscript has been authored by Battelle Energy Alliance, LLC under Contract No. DE-AC07-05ID14517 with the U.S. Department of Energy. The United States Government retains and the publisher, by accepting the article for publication, acknowledges that the United States Government retains a nonexclusive, paid-up, irrevocable, world-wide license to publish or reproduce the published form of this manuscript, or allow others to do so, for United States Government purposes.

\section{REFERENCES}

1. O'Brien, J. E., "Review of the Potential of Nuclear Hydrogen for Addressing Energy Security and Climate Change," Nuclear Technology, Vol. 178, April 2012.

2. O'Brien, J. E., McKellar, M. G., Harvego, E. A., and Stoots, C. M., "High-Temperature Electrolysis for Large-Scale Hydrogen and Syngas Production from Nuclear Energy - Summary of System Simulation and Economic Analysis," Int. J. of Hydrogen Energy, Vol. 35, issue 10, pp. 4808-4819, May 2010.

3. O'Brien, J. E., “Thermodynamics and Transport Phenomena in High Temperature Steam Electrolysis Cells," Journal of Heat Transfer, Vol. 134, pp. 031017: 1- 11, March 2012.

4. T. Ramsdem, D. Steward, and J. Zuboy, "Analyzing the Levelized Cost of Centralized and Distributed Hydrogen Production Using the H2A Production Model, Version 2", NREL/TP-560-46267, September 2009
5. J. Ivy, " Summary of Electrolytic Hydrogen Production", Milestone Completion Report, NREL/MP-560-36734, September 2004

6. http://matche.com/EquipCost

7. http://www.cheresources.com/uexchangers.shtml

8. H. P. Loh and Jennifer Lyons, "Process Equipment Cost Estimation - Final Report", DOE/NETL2002/1169

9. K. M. Guthrie, " Data and Techniques for preliminary Capital Cost Estimating", Chemical Engineering, March 1969

10. Dominion Engineering, Inc., "Preliminary Evaluation of 160 TPD HTSE Hydrogen Plant Capital Costs", M6917-00-01, Rev. 0 DRAFT A, August 2010

11. E. A. Harvego, M. G. McKellar, M. S. Sohal, J. E. O'Brien, J. S. Herring, "Economic Analysis of the Reference Design for a Nuclear-Driven HighTemperature-Electrolysis Hydrogen Production Plant", INL/EXT-08-13799, January 2008 